\title{
Retraction
}

\section{RETRACTED: "Mahendra Yadav, Sushil Kumar, Indra Bahadur, Deresh Ramjugernath, Electrochemical and Quantum Chemical Studies on Synthesized Phenylazopyrimidone Dyes as Corrosion Inhibitors for Mild Steel in a $15 \% \mathrm{HCl}$ Solution [Int. J. Electrochem. Sci., 9 (2014) 3928 - 3950]"}

Published: 7 September 2016

This article has been retracted at the request Editor-in-Chief. Main reason for the decision is higher similarity with perviously published papers by the authors.

(C) 2016 Published by ESG (www.electrochemsci.org). This article is an open access article distributed under the terms and conditions of the Creative Commons Attribution license (http://creativecommons.org/licenses/by/4.0/). 